\title{
ANALISIS DAYA SAING USAHATANI KOPI LIBTUKOM DI KABUPATEN TANJUNG JABUNG BARAT
}

Analysis Competitiveness Of Libtukom Coffee Farming In Districts Of West Tanjung Jabung

\author{
POPY HANDAYANI ${ }^{1}$, SUANDI ${ }^{2}$ DAN FUAD MUCHLIS ${ }^{3}$ \\ ${ }^{1)}$ Alumni Program Studi Agribisnis Proram Pasca Sarjana UNJA \\ ${ }^{2)}$ Dosen Program Studi Agribisnis Proram Pasca Sarjana UNJA \\ Email: popynisa@gmail.com
}

Diterima : 06 Maret 2020; Direvisi : 25 Maret 2020; Disetujui : 13 April 2020

https://doi.org/10.37250/newkiki.v4i1.58

\begin{abstract}
Entering the era of free trade in 2015 in the ASEAN Economic Community (MEA) and 2020 around the world through WTO (World Trade Organization) agreement, many things must be considered, each country is required to improve its competitiveness through development in various sectors of the economy especially the goods to be exported to the destination country. The purpose of this research is to analyze the competitiveness of Libtukom Coffee (competitive and comparative advantage), analyze the impact of government policy on output and input on libtukom coffee farming and analyze competitiveness sensitivity of Libtukom coffee farming to change of output and input. This study uses primary and secondary data sources with number of respondents as much as 92 respondents. The data obtained were analyzed by using PAM (Policy Analysis Matrix) method. From the result of the research, it can be concluded that: (1) Cultivation of libtukom coffea in Distric of West Tanjung Jabung has comparative and competitive advantage. The use of resources in the research area at the market and international market rates is efficient for economic and financial use as indicated by PCR and DRCR values obtained <1, for PCR obtained 0.195 and DRCR 0.176; (2) In general, local government policies for leather farming still have not shown favorable partiality for small farmers. This can be seen from the result of NPCO value is 0.912 and seen from NPCI is 1.006 and (3) In the simulation of sensitivity done obtained the production costs incurred by farmer for libtukom coffee cultivation can be covered by the selling price earned.
\end{abstract}

Keywords : Policy Analysis Matrix, Analyze The Competitiveness, Libtukom Coffea Farming

\begin{abstract}
Abstrak
Memasuki era perdagangan bebas 2015 di kawasan ASEAN Masyarakat Ekonomi Asian (MEA) dan 2020 di seluruh dunia melalui kesepakatan WTO (World Trade Organization), banyak hal yang harus dipertimbangkan diantaranya setiap negara dituntut untuk meningkatkan daya saingnya melalui pembangunan di berbagai sektor perekonomian terutama barang yang akan di ekspor ke negara tujuan.

Tujuan penelitian ini adalah menganalisis daya saing usahatani Kopi Libtukom, dampak kebijakan pemerintah dan sensitivitas daya saing usahatani Kopi Libtukom di Kabupaten Tanjung Jabung Barat. Penelitian menggunakan data primer dan sekunder dengan jumlah sampel responden sebanyak 92 responden. Data yang diperoleh dianalisis menggunakan metode PAM (Policy Analysis Matrix). Hasil penelitian menunjukkan : (1) Usahatani Kopi Libtukom di Kabupaten Tanjung Jabung Barat memiliki keunggulan komparatif dan kompetitif yang ditandai dengan nilai PCR dan DRCR $<1$. Untuk PCR diperoleh 0,195 dan DRCR 0,176; (2) Secara umum kebijakan-kebijakan pemerintah daerah untuk usahatani Kopi Libtukom belum menunjukkan keberpihakan yang menguntungkan petani kecil. Hal ini terlihat dari hasil nilai NPCO sebesar 0.912 dan nilai NPCI sebesar 1.006; dan (3) Simulasi sensitivitas yang dilakukan diperoleh biaya produksi yang dikeluarkan oleh petani dapat ditutupi oleh harga jual Kopi Libtukom itu sendiri.
\end{abstract}

Kata Kunci : Daya Saing, Usahatani Kopi Libtukom, Policy Analisis Matrix

692 | Khazanah Intelektual Volume 4 Nomor 1 Tahun 2020 
PENDAHULUAN

Memasuki era perdagangan bebas tahun 2015 di kawasan ASEAN Masyarakat Ekonomi Asian (MEA) dan tahun 2020 di seluruh dunia melalui kesepakatan WTO (World Trade Organization), banyak hal yang harus dipertimbangkan diantaranya setiap negara dituntut untuk meningkatkan daya saingnya melalui pembangunan di berbagai sektor perekonomian terutama barang yang akan diekspor ke negara tujuan. Lebih lanjut Kumar, dkk. (2002), mengatakan masa sekarang persaingan antar negara di pasar global akan semakin ketat oleh sebab itu daya saing menjadi kata kunci karena mencerminkan indikator dari sisi produktivitas, biaya dan teknologi.

Negara yang memiliki daya saing tinggi akan memiliki kemampuan yang lebih besar untuk tetap bertahan dan melakukan penetrasi serta penguasaan pasar internasional. Sebaliknya, negara-negara yang tidak mempunyai karakter tersebut tidak akan mampu mengembangkan ekspor bahkan komoditas negara pesaing akan masuk ke negara tersebut (Novianti, 2003).

Salah satu sektor perekonomian yang memegang peranan penting dalam pembangunan ekonomi di Indonesia adalah sektor pertanian. Peranan itu ditunjukkan dengan sumbangan sektor pertanian terhadap pertumbuhan ekonomi, penyedia lapangan kerja, sumber devisa dan penyedia bahan baku. Untuk menciptakan nilai tambah di sektor industri dan jasa.

Periode tahun 2006-2015 laju pertumbuhan nilai ekspor sebagian komoditas mengalami percepatan, yaitu Kakao, Tembakau, Teh, Kelapa Sawit, Karet, Kopi, Kelapa, Tebu dan Kulit Kayu Manis. Walaupun perkembangan ekspor Kopi Indonesia berfluktuatif selama periode 2006-2015, namun dilihat dari trennya cenderung meningkat. Tahun 2006 volume ekpor Kopi Indonesia tercatat sebanyak 413.500 ton dengan nilai ekspor sebesar 586.877 US\$, Tahun 2015 menjadi sebesar 502.021 ton dengan nilai ekspor sebesar 1.197.735 US\$.

Salah satu kabupaten di Provinsi Jambi yang menjadikan Kopi sebagai komoditas unggulan yang memberikan kontribusi PDRB yang cukup besar dengan nilai rata-rata kontribusi sebesar 23,28 persen per tahun adalah Kabupaten Tanjung Jabung Barat yang dikenal dengan Kopi Liberika Tungkal Komposit (Libtukom). Secara makro Kopi Libtukom merupakan salah faktor penting yang berperan terhadap 
perekonomian wilayah Kabupaten Tanjung Jabung Barat. Selain menjadi penyumbang devisa, usahatani Kopi Libtukom menjadi mata pencaharian 2.436 keluarga petani.

Luas penanaman Kopi Libtukom tahun 2011 tercatat seluas 2.538 ha dengan produksi 1.113 ton dan angka ini terus mengalami peningkatan meskipun dalam jumlah yang tidak terlalu besar sampai tahun 2017 luas tanam Kopi Libtukom tercatat seluas 2.610 ha dengan produksi sebesar 1.079 ton. Tahun 2017 produktivitas Kopi Libtukom di Kabuptaen Tanjung Jabung Barat tercatat sebesar $841 \mathrm{~kg} / \mathrm{ha}$ (Disbun Provinsi Jambi, 2017).

Berdasarkan fakta tersebut perlu dilakukan penelitian yang bertujuan untuk : (1) Menganalisis daya saing usahatani Kopi Libtukom (keunggulan kompetitif dan komparatif); Menganalisis dampak kebijakan pemerintah terhadap output dan input pada usahatani Kopi Libtukom; dan (3) Menganalisis sensitivitas daya saing usahatani Kopi Libtukom terhadap perubahan output dan input.

\section{METODE PENELITIAN}

Penelitian ini dilakukan di Kabupaten Tanjung Jabung Barat Provinsi Jambi pada bulan Maret sampai bulan April 2019. Penelitian ini menggunakan sumber data primer dan sekunder. Pengambilan sampel dilakukan terhadap petani, pedagang perantara/pengumpul dan pedagang input-input pertanian. Pengambilan sampel ini dilakukan dengan menggunakan teknik purposive sampling, yaitu teknik pengambilan sampel secara sengaja dengan pertimbangan luas areal tanaman kopi, jumlah petani dan kapasitas produksi yang paling tinggi di Kabupaten Tanjung Jabung Barat.

Analisis data merupakan proses yang bertujuan untuk menyederhanakan data yang diperoleh dalam bentuk yang lebih mudah dibaca, dimengerti serta diinterprestasikan sehingga memberikan keterangan gambaran yang ada. Data yang diperoleh nantinya akan dianalisis dengan menggunakan metode analisis sebagai berikut :

a. Analisis Deskriftif, digunakan untuk membuat atau menggambarkan (deskripsi) mengenai perkembangan Kopi Libtukom yang didukung oleh penjelasan empiris serta kaitan daya saing dari pengaruh kebijakan pemerintah.

b. Metode Infrensial, data yang diperoleh ditabulasi dan diolah 
dengan menggunakan metode PAM

(Policy Analysis Matrix) yang dikembangkan oleh Monke dan Pearson sejak tahun 1989. Metode PAM merupakan alat analisis yang digunakan untuk mengetahui efisiensi ekonomi dan besarnya insentif atau dampak intervensi dalam pengusahaan berbagai aktivitas usahatani secara keseluruhan dan sistematis. Analisis ini dapat digunakan pada sistem komoditas dengan berbagai wilayah, tipe usahatani dan teknologi. Analisis PAM juga dapat digunakan untuk mengetahui apakah suatu kebijakan dapat memperbaiki daya saing terhadap pengusahaan suatu komoditas yang dihasilkan melalui efisiensi usaha dan pertumbuhan pendapatan. Matrix PAM dapat dilihat pada Tabel 1.

Tabel 1. Policy Analysis Matrix (PAM)

\begin{tabular}{|l|c|c|c|c|}
\hline & Penerimaan & $\begin{array}{c}\text { Biaya } \\
\text { Input Tradable }\end{array}$ & $\begin{array}{c}\text { Biaya } \\
\text { Faktor Domestik }\end{array}$ & Keuntungan \\
\hline Privat & A & B & C & D=A-B-C \\
\hline Sosial & E & F & G & H=E-F-G \\
\hline Divergensi & I=A-E & J=B-F & K=C-G & L=I-J-K \\
\hline \hline
\end{tabular}

$\mathrm{A}=$ Total Penerimaan tradable usahatani kopi libtukom pada harga privat;

$\mathrm{B}=$ Total biaya tradable usahatani kopi libtukom pada harga privat;

$\mathrm{C}=$ Total biaya non tradable usahatani kopi libtukom pada harga privat;

$\mathrm{D}$ = Tingkat keuntungan pada harga privat;

$\mathrm{E}=$ Penerimaan usahatani kopi libtukom pada harga sosial;

$\mathrm{F}$ = Total biaya tradable usahatani kopi libtukom pada harga sosial;

$\mathrm{G}=$ Total biaya non tradable usahatani kopi libtukom pada harga sosial;

$\mathrm{H}=$ Keuntungan sosial;

$\mathrm{I}=$ Output transfer;

$\mathbf{J}=$ Input Transper;

$\mathrm{K}=$ Faktor Transfer; dan

$\mathrm{L}=$ Net Transfer.

c. Analisis Daya saing $(\mathrm{PP})$, yaitu $\mathrm{D}=\mathrm{A}-(\mathrm{B}+\mathrm{C})$ dan mencari

Analisis Keuntungan, dihitung harga Sosial Profitability (SP), yaitu $\mathrm{H}$ dengan mencari Private Profitability $=\mathrm{E}-(\mathrm{F}+\mathrm{G})$. 
d. Efisiensi Finansial dan Efisiensi Ekonomi

Untuk menjawab tujuan pertama dilakukan dengan melihat :

- Private Cost Rasio $(\mathrm{PCR})=\mathrm{C} /(\mathrm{A}$ B) Apabila nilai PCR $<1$ dan nilainya makin kecil, berarti sistem produksi usahatani Kopi Libtukom semakin kompetitif dan mampu membiayai faktor domestik pada harga privat dan kemampuan tersebut akan meningkat. Sebaliknya bila, $\mathrm{PCR} \geq 1$, sistem komoditas yang diteliti tidak memiliki keunggulan kompetitif.

- Domestic Resources Cost Ratio $(\mathrm{DRCR})=\mathrm{G} /(\mathrm{E}-\mathrm{F})$, Jika DRCR $<$ 1, maka sistem komoditas mempunyai keunggulan komparatif, bila $\geq 1$ sistem komoditas tidak memiliki keunggulan komparatif.

e. Dampak Kebijakan Pemerintah

Untuk menjawab tujuan kedua dilakukan dengan melihat :

- Kebijakan terhadap Output yaitu Output Transfer (OT) : I = A - E dan Nominal Protection Coefficient on Output (NPCO) $=$ $\mathrm{A} / \mathrm{E}$

- Kebijakan terhadap Input yaitu Input Transfer (IT) : $\mathrm{J}=\mathrm{B}-\mathrm{F}$ dan Nominal Protection Coefficien on Tradable Input
$(\mathrm{NPCI})=\mathrm{B} / \mathrm{F}$ serta Transfer

Factor (TF) : K = C - G

- Kebijakan terhadap Input-Output yaitu Effective Protection Coefficient $(\mathrm{EPC})=(\mathrm{A}-\mathrm{B}) /(\mathrm{E}-\mathrm{F})$, Net Transfer (NT): $\mathrm{L}=\mathrm{D}-\mathrm{H}$, Profitability Coefficient $(\mathrm{PC})=\mathrm{D} /$ $\mathrm{H}$ dan Subsidy Ratio to Producer $(\mathrm{SRP})=\mathrm{L} / \mathrm{E}$

f. Analisis Sensitivitas

Analisis sensitivitas untuk melihat bagaimana hasil analisis suatu aktivitas ekonomi bila terjadi perubahan terhadap input dan output. Perubahan yang dimasukkan pada penelitian ini adalah perubahan harga output dan input. Jika analisis sensitivitas yang dlakukan pada penelitian ini adalah sebagai berikut : Penurunan output sebesar 5 persen, penurunan harga output sebesar 10 persen dan peningkatan harga pupuk anorganik sebesar 12,5 persen. Kenaikan harga pupuk urea sebesar 12,5 persen pada tahun 2016 yang ditetapkan berdasarkan kenaikan Harga Eceran Tertinggi (HET) pupuk bersubsidi dalam Peraturan Menteri Pertanian Nomor 60/Permentan/SR. 130/12/2015 akan mempengaruhi biaya input tradable yang akan dikeluarkan petani. 
HASIL DAN PEMBAHASAN

\section{a. Penggunaan Faktor Produksi Usahatani}

Bibit yang digunakan adalah bibit Kopi Libtukom yang berasal dari indukan yang memiliki keunggulan lebih tahan terhadap serangan hama dan penyakit terutama penyakit yang berasal dari jamur yang umumnya menyerang tanaman Kopi Liberika. Jarak tanam yang digunakan dalam penanaman bibit Kopi Libtukom di daerah penelitian adalah $3 \mathrm{mx} 3 \mathrm{~m}$ atau $3 \mathrm{mx} 4 \mathrm{~m}$ dan setiap lubang tanam sebanyak satu bibit kemudian ditutup dengan tanah. Pupuk yang digunakan oleh petani adalah pupuk Urea, SP 36 dan $\mathrm{KCl}$ sedangkan obat-obatan menggunakan Roundup dan Decis. Pemupukan sebaiknya dilakukan 3 sampai 4 kali dalam setahun.

Faktor produksi yang digunakan dalam menghitung biaya produksi dalam penelitian ini adalah lahan, bibit, tenaga kerja dalam dan luar keluarga, pupuk, obat-obatan dan alat pertanian. Rata-rata penggunaan lahan sebesar 1,25 ha. Dengan bibit sebanyak 900$1000 \mathrm{btg} / \mathrm{ha}$ di daerah penelitian dan harga bibit sebesar Rp 3000/btg. Penggunaan tenaga kerja dalam dan luar keluarga memiliki rata-rata sebesar 44,49 HOK/ha dengan upah tenaga kerja sebesar Rp 68.202,00.

PPL setempat telah memberikan anjuran tentang penggunaan pupuk untuk masing-masing jenis. Luas lahan sebesar 1 ha sebaiknya diberikan pupuk urea sebanyak $150 \mathrm{~kg}$, pupuk SP 36 sebanyak $125 \mathrm{~kg}$ dan $\mathrm{KCl} 120 \mathrm{~kg}$. Namun, dosis penggunaan pupuk yang dilakukan petani pada kenyataannya belum mendekati dosis anjuran tersebut karena dosis penggunaan pupuk Urea di daerah penelitian hanya memiliki rata-rata sebesar 44,61 kg/ha dan rata-rata dosis penggunaan pupuk SP 36 sebesar 26,74 kg/ha, hanya pemberian pupuk $\mathrm{KCl}$ yang sesuai rekomendasi.

Penggunaan pupuk yang belum sesuai anjuran dipengaruhi oleh kurangnya pengetahuan dan kesadaran petani untuk memberikan pupuk sesuai dengan anjuran. Harga pupuk Urea, SP 36 dan $\mathrm{KCl}$ yang beredar di daerah penelitian masing-masing sebesar Rp. $\quad 3.500 / \mathrm{kg}$, Rp. $\quad 5.000 / \mathrm{kg}$ dan Rp. $6.000 / \mathrm{kg}$.

Adapun rata-rata penggunaan herbisida cair (Roundap) sebesar 1 1/ha dan rata-rata penggunaan pestisda cair (Decis) sebesar 2.32 1/ha yang 
digunakan petani dalam kegiatan pemeliharaan usahatani di daerah penelitian dengan harga beli Roundap Rp. 89.769/L dan harga beli Decis
Rp. 55.000/l. Biaya penyusutan alat terbesar berturut-turut adalah sekop Rp. 12.501; cangkul Rp. 31.242; parang Rp. 4.683 dan terpal Rp 1.037.

Tabel 2. Rata-rata Penggunaan Faktor Produksi Usahatani di Daerah Penelitian dalam 1 (satu) Musim Tanam

\begin{tabular}{|c|c|c|c|c|c|}
\hline No. & Uraian & Satuan & Jumlah & Biaya (Rp) & $\begin{array}{c}\text { Total } \\
\text { Biaya }(\mathbf{R p})\end{array}$ \\
\hline \multicolumn{6}{|c|}{ A. Tradable input } \\
\hline 1 & $\mathrm{KCl}$ & $\mathrm{Kg}$ & $1,242.04$ & 1,000 & $1,242,041$ \\
\hline 2 & Urea & $\mathrm{Kg}$ & 44.61 & 1,993 & 88,933 \\
\hline 3 & SP 36 & $\mathrm{Kg}$ & 26.74 & 2,444 & 65,359 \\
\hline 4 & Herbisida cair & Liter & 1.00 & 89,769 & 89,769 \\
\hline 5 & Pestisida cair & Liter & 2.32 & 55,000 & 127,398 \\
\hline B & Faktor Domestik & & & & \\
\hline B.1 & Tenaga kerja & $\mathrm{HOK}$ & 54.34 & 68.302 & 3.706 .113 \\
\hline \multirow[t]{5}{*}{ B.2 } & Pengangkutan & & & & \\
\hline & a. dalam keluarga & hok & 3.00 & 22,895 & 68,685 \\
\hline & b. luar keluarga & hok & 2.44 & 48,500 & 118,281 \\
\hline & c. Motor & hk & 1.00 & 186,634 & 186,634 \\
\hline & d. Mobil & hk & 1.00 & 100,000 & 100,00 \\
\hline B.3 & Sewa Lahan & ha & 1.37 & $5,000,000$ & $6,836,735$ \\
\hline B.4 & Modal & & & & \\
\hline 1 & Bibit & $\mathrm{Rp}$ & $7,102,040.82$ & 0.25 & $1,775,510$ \\
\hline \multirow[t]{5}{*}{ B.5 } & Penyusutan alat: & & & & \\
\hline & a. sekop & unit & 1.06 & 12,501 & 12,501 \\
\hline & b. cangkul & unit & 1.49 & 31,242 & 31,242 \\
\hline & c. parang & unit & 1.69 & 4,683 & 4,683 \\
\hline & d. terpal & unit & 1.00 & 1,037 & 1,037 \\
\hline
\end{tabular}

Sumber : Data Primer, 2019

\section{b. Penentuan Alokasi Domestik dan Asing}

Metode pengalokasian biaya dalam komponen domestik dan asing menggunakan metode pendekatan total (Total Approach). Metode pendekatan total mengasumsikan semua biaya input tradable dibagi dengan komponen biaya domestik dan asing serta penambahan input tradable dapat dipenuhi dari produksi domestik jika input tersebut memiliki kemungkinan untuk diproduksi dalam negeri.

Adapun alokasi biaya asing dan domestik ditunjukkan dalam Tabel 3. 
Tabel 3. Alokasi Komponen Biaya Input-Output Usahatani Kopi Libtukom dalam Komponen Domestik dan Asing (persen) Tahun 2018

\begin{tabular}{|c|c|c|c|c|c|}
\hline \multirow{2}{*}{ Uraian } & \multicolumn{2}{|c|}{ Finansial } & \multicolumn{3}{|c|}{ Ekonomi } \\
\hline & Domestik & Asing & Pajak & Domestik & Asing \\
\hline \multicolumn{6}{|l|}{ A. Penerimaan } \\
\hline Output Kopi Libtukom* & 98,9 & 0 & 1,1 & 100 & 0 \\
\hline \multicolumn{6}{|l|}{ B. Pengeluaraan Input } \\
\hline Pupuk* & & & & & \\
\hline - Urea & 70 & 29,8 & 0,2 & 71 & 29 \\
\hline - $\mathrm{KCl}$ & 70 & 29,8 & 0,2 & 71 & 29 \\
\hline - SP 36 & 70 & 29,8 & 0,2 & 71 & 29 \\
\hline Bibit* & 100 & 0 & 0 & 100 & 0 \\
\hline Pestisida dan Herbisida** & & & & & \\
\hline Herbisida & 79,67 & 19,06 & 1,27 & 80,94 & 19,06 \\
\hline Pestisida & 79,67 & 19.06 & 1,27 & 80,94 & 19,06 \\
\hline Peralatan Pertanian* & 96,8 & 0 & 3,2 & 100 & 0 \\
\hline Tenaga Kerja* & 98,3 & 0 & 1,7 & 100 & 0 \\
\hline Biaya lainnya* & & & & & \\
\hline Sewa Lahan & 100 & 0 & 0 & 100 & 0 \\
\hline Transportasi & 100 & 0 & 0 & 100 & 0 \\
\hline
\end{tabular}

Sumber : Olahan Data Primer, 2019

Sulitnya informasi mengenai harga Free On Board (FOB) Kopi Libtukom Indonesia tahun 2018 menyebabkan border price yang digunakan dalam penelitian ini adalah CIF (Cost, Insurance and Freight). Berdasarkan informasi harga yang diperoleh dari International Monetary Fund (IMF), diketahui bahwa harga CIF kopi di pasar internasional New York dan Singapura adalah sebesar 1.600 US Dollar/ton. Biaya pengapalan (freight) dan asuransi (insurance) serta biaya lainnya dari Indonesia ke New York (NYBOT) sebesar 45 US Dollar/ton sehingga harga FOB kopi di Indonesia yang diperoleh dari Dinas Perkebunan Provinsi Jambi sebesar 3.000 US Dollar/ton. Nilai tersebut kemudian dikonversikan dengan nilai tukar bayangan (SER) sebesar Rp. 12.732,1 per US Dollar tahun 2017. Hasil yang diperoleh kemudian dikurangi dengan biaya transportasi dan 
pengepakan dari pedagang besar terdekat ke pelabuhan Tanjung Priok Rp. 90/kg. Terakhir, biaya distribusi Kopi Libtukom dari petani ke pedagang besar dikurangkan dari harga paritas tingkat pedagang besar Rp. 90/kg karena Kopi Libtukom merupakan output. Berdasarkan hasil perhitungan tersebut, harga bayangan Kopi Libtukom di tingkat petani di Kabupaten Tanjung Jabung Barat sebesar Rp 38.390/kg.

\section{Harga Sosial Input}

Harga sosial input dalam usahatani Kopi Libtukom Kabupaten Tanjung Jabung Barat meliputi pupuk, pestisida, perlatan pertanian, tenaga kerja dan lahan. Perhitungan harga sosial pupuk urea pada penelitian ini menggunakan harga internasional. Berdasarkan harga FOB Urea di World Bank (2017), yakni sebesar 340 U\$ Dollar/ton

Nilai yang didapat kemudian ditambahkan dengan biaya pengapalan dan asuransi sebesar 10\% dari harga FOB, sehingga didapatkan nilai CIF Indonesia sebesar 276,4 U\$ Dollar/ton kemudian dikonversikan dengan nilai tukar bayangan (SER) tahun 2017 sebesar Rp. 12.732,1 per U\$ Dollar.
Harga CIF dalam mata uang domestik sebesar Rp. 4.100,-/kg kemudian ditambah dengan biaya transportasi dan bongkar muat masing-masing sebesar Rp. 90,-/kg dan Rp. 14,-/kg. Harga di pedagang besar Rp. 3.520,43/kg ditambah biaya distribusi di tingkat petani Rp. 120,-/kg sehingga harga bayangan pupuk Urea di tingkat petani sebesar Rp 3.714,-/kg.

Penetuan harga sosial pupuk SP36 berdasarkan harga FOB compound fertilizer dalam World Bank (2017), yakni sebesar 350 U\$ Dollar/ton. Nilai tersebut kemudian ditambahkan dengan biaya pengapalan dan asuransi sebesar $10 \%$ sehingga harga CIF Indonesia sebesar 234,62 U\$ Dollar/ton. Selanjutnya, nilai tesebut dikalikan dengan nilai tukar bayangan (SER) tahun 2017 sebesar Rp. 12.732,1 per U\$ Dollar, kemudian ditambah dengan biaya transportasi dan bongkar muat. Harga yang telah beredar di pedagang besar sebesar Rp. 5.345/,-kg kemudian ditambah dengan biaya distribusi ke desa sehingga harga bayangan pupuk SP36 di tingkat petani sebesar Rp. 5.368,-/kg

Fitria Astirani (2011), harga sosial pestisida dapat didekati dengan harga rata-rata privat kemudian 
ditambah dengan ppn 10 persen maka harga sosial pestisida sebesar Rp. 98.756,-/liter dan harga bayangan herbisida sebesar Rp. 60.000,-/liter.

Perhitungan harga sosial bibit pada penelitian adalah harga sosial bibit berupa harga sosialnya sebagai output. Perhitungan harga sosial bibit dilakukan dengan cara harga aktual (privat) bibit dibagi dengan harga aktual output kemudian dikalikan dengan harga sosial output sehingga harga sosial bibit dalam penelitian ini adalah Rp. 3.291,-/btg.

Penghitungan upah tenaga kerja di daerah penelitian dalam harga privat sama dengan upah tenaga kerja sosial, dikarenakan seluruh tenaga kerja yang digunakan adalah tenaga kerja tidak terampil dan para peneliti berpendapat tidak ada divergensi di pasar tenaga kerja pertanian tidak terampil di pedesaan (Pearson, dkk., 2005).

Pendekatan yang dilakukan untuk menentukan harga sosial lahan di daerah penelitian adalah nilai sewa lahan yang berlaku di daerah setempat. Hasil wawancara yang telah dilakukan diperoleh informasi bahwa nilai sewa lahan di daerah penelitian adalah sebesar Rp. 3.500.000,-/ha.

\section{Harga Sosial Nilai Tukar}

Penentuan harga sosial nilai tukar uang menurut Squire dan Van Der Tak dalam Gittinger (1986), nilai tukar resmi dibagi dengan faktor konversi standar yang berlaku. Nilai faktor konversi standar ditentukan berdasarkan nilai ekspor ditambah dengan nilai impor kemudian dibagi dengan penjumlahan antara nilai ekspor dikurang pajak ekspor dan nilai impor ditambah pajak impor pada tahun yang sama (Rosegrant, 1987 dalam Gittinger, 1986).

Penentuan nilai tukar sosial dalam penelitian ini menggunakan data tahun 2017 yang bersumber dari data ekspor dan impor BPS. Total ekspor pada tahun 2017 mencapai Rp. 195.000. miliar dan impor sebesar Rp. 165.390 miliar. Penerimaan pajak untuk ekspor dan impor tahun 2017 masing-masing sebesar Rp. 35.700 miliar dan Rp. 3.000 miliar sehingga faktor konversi standar sebesar 1,10. Nilai tukar resmi rupiah yang berlaku tahun 2017 sebesar Rp. 13.882,52,- per 1 U\$ Dollar dan kemudian dibagi dengan faktor konversi standar sebesar 1,10 sehingga nilai tukar sosial tahun 2017 sebesar Rp 12.732,1. 
c. Analisis Daya Saing Kopi Libtukom Kabupaten Tanjung Jabung Barat

\section{Analisis Daya Saing}

Berdasarkan keuangan dan analisis ekonomi hasil, pendapatan keuangan bersih yang diperoleh Kopi Libtukom secara privat di Kabupaten Tanjung Jabung Barat dalam satu kali tanam menunjukkan bahwa ratarata total penerimaan mencapai Rp. 54.955.706,32/ha, sedangkan total biaya yang dikeluarkan petani sebesar Rp. 11.264.894,12/ha. Sehingga keuntungan bersih (net profit) sebesar Rp. 43.690.812,2/ha. Ini berarti bahwa usahatani Kopi Libtukom menguntungkan bagi petani secara individual.
Dengan kata lain, biaya produksi yang dikeluarkan oleh masing-masing petani dapat ditutupi oleh harga jual Kopi Libtukom.

Selain itu, masing-masing biaya produksi pada harga privat dan sosial dibagi dengan biaya input tradable dan faktor domestik. Setelah perhitungan dilakukan, maka disusunlah tabel PAM yang dapat dilihat pada Tabel 4. Data penerimaan, biaya dan keuntungan pada tabel tersebut selanjutnya digunakan untuk menghitung nilai-nilai yang menjadi indikator daya saing dan dampak kebijakan pemerintah terhadap daya saing Kopi Libtukom di Kabupaten Tanjung Jabung Barat.

Tabel 4. Policy Analysis Matrix (PAM) Sistem Komoditas Kopi Libtukom di Kabupaten Tanjung Jabung Barat (Rp/ha)

\begin{tabular}{|c|c|c|c|c|c|}
\hline \multirow{2}{*}{ Items } & \multirow{2}{*}{ Penerimaan } & \multirow{2}{*}{$\begin{array}{c}\text { Biaya } \\
\text { Input } \\
\text { Tradable }\end{array}$} & \multicolumn{2}{|c|}{$\begin{array}{c}\text { Biaya } \\
\text { Faktor Domestik }\end{array}$} & \multirow[t]{2}{*}{ Keuntungan } \\
\hline & & & $\begin{array}{l}\text { Tenaga } \\
\text { Kerja }\end{array}$ & $\begin{array}{c}\text { Lahan \& } \\
\text { Modal }\end{array}$ & \\
\hline Private & $54.955 .706,32$ & $676.883,13$ & 2.403 .928 & $8,184.083$ & $43.690 .812,2$ \\
\hline Sosial & $60.279 .030,29$ & $673.175,17$ & $1,964.503$ & $8,529,302$ & $49.112 .049,9$ \\
\hline Divergensi & $(5.323 .323,77)$ & $3.707,96$ & 439.425 & $(345.2219)$ & $(5.421 .237,7)$ \\
\hline
\end{tabular}

Sumber : Olahan Data Primer, 2019

Tabel 4 menunjukkan bahwa

sistem usahatani Kopi Libtukom di Kabupaten Tanjung Jabung Barat menguntungkan baik secara finansial maupun ekonomi. Keuntungan privat

dan keuntungan sosial menunjukkan nilai positif namun kalau dicermati lagi terlihat pada Tabel 4 profitabilitas privat usahatani Kopi Libtukom lebih kecil dibanding profitabilitas sosialnya. 
Perbedaan ini terjadi diduga karena adanya praktek monopsoni di lokasi penelitian.

Kenyataan di lapangan menunjukkan bahwa adanya ketergantungan para petani pada pedagang pengumpul desa atau dengan kata lain para pedagang pengumpul di masingmasing desa penelitian menjadi satusatunya pembeli hasil panen dan tempat bergantung petani untuk aspek keuangan serta pengadaan input. Sehingga para pedagang pengumpul tersebut memiliki kekuatan dalam mengendalikan pasar input dan output, akibatnya harga jual input menjadi tinggi sementara harga beli output justru ditekan.

Penyebab lain terjadinya divergensi adalah kebijakan pemerintah yang distorsif. Penerapan kebijakan distorsif untuk mencapai tujuan yang bersifat non-efisiensi (pemerataan atau ketahanan pangan), akan menghambat terjadinya alokasi sumberdaya yang efisien dan dengan sendirinya akan menimbukan divergensi. Misalnya, tarif impor beras yang diterapkan untuk meningkatkan pendapatan petani (tujuan pemerataan) dan meningkatkan produksi beras dalam negeri (tujuan ketahanan pangan), namun dilain pihak akan menimbulkan kerugian efisiensi bila harga beras impor yang digantikannya ternyata lebih murah dari biaya domestik yang digunakan untuk memproduksi beras dalam negeri, sehingga akan timbul trade-offs (Pearson dkk, 2005).

Secara teori, kebijakan yang paling efisien dapat dicapai jika pemerintah mampu menciptakan kebijakan yang menghapuskan kegagalan pasar dan mengabaikan tujuan non-efisiensi serta menghapuskan kebijakan yang distorsif. Apabila tindakan menciptakan kebijakan yang efisien dan menghilangkan kebijakan yang distorsif tersebut mampu dilaksanakan, maka divergensi dapat dihilangkan dan efek divergensi (nilai-nilai divergensi pada Tabel 4) akan menjadi nol. Pada kondisi seperti itu, nilai-nilai pada bagian privat (baris pertama tabel PAM) akan sama dengan nilai pada bagian sosial (baris kedua tabel PAM) atau dengan kata lain pendapatan (revenue), biaya dan profitabilitas privat akan sama dengan pendapatan, biaya dan profitabilitas sosial.

\section{Analisis Keunggulan Kompetitif}

Analisis keunggulan kompetitif usahatani Kopi Libtukom di Kabupaten 
Tanjung Jabung Barat dapat diukur dengan indikator Rasio Biaya Privat (PCR) dan Keuntungan Privat (PP). Data mengenai besarnya PCR dan PP usahatani kopi libtukom di Tanjung Jabung Barat yang diperoleh keuntungan privat Rp. 43.690.812,2/ha dengan nilai PCR yang didapatkan sebesar 0,195.

Kondisi keunggulan kompetitif usahatani Kopi Libtukom di Kabupaten Tanjung Jabung Barat dapat didekati dengan melihat alokasi sumberdaya untuk mencapai efisiensi secara finansial dalam usahatani Kopi Libtukom. Efisiensi secara finansial diukur dengan menggunakan indikator PCR. PCR merupakan rasio antara biaya faktor domestik dengan nilai tambah output dari biaya input tradable pada harga privat atau harga yang didalamnya terdapat kebijakan pemerintah. Nilai PCR menunjukkan kemampuan suatu sistem usahatani komoditas dalam membiayai faktor domestiknya pada harga privat. Semakin kecil nilai PCR maka semakin besar tingkat keunggulan kompetitif dari pengusahaan suatu komoditas.

Kondisi yang sama juga terlihat dari besarnya keuntungan privat (PP) yang diperoleh dari sistem usahatani
Kopi Libtukom dalam satu kali musim tanam adalah Rp. 54.955.706.52/ha, sedangkan total biaya yang dikeluarkan petani sebesar Rp. 11.264.894,32/ha. Sehingga keuntungan bersih (net profit) sebesar Rp. 43,690,812,2/ha.

Keuntungan privat merupakan selisih antara penerimaan dengan seluruh biaya yang dikeluarkan pada sistem usahatani Kopi Libtukom per hektar pada harga pasar (privat), yakni harga yang didalamnya terdapat kebijakan pemerintah seperti subsidi dan pajak. Secara teoritis perolehan nilai PCR tersebut dapat dikemukakan bahwa untuk meningkatkan nilai tambah output sebesar satu satuan pada harga privat maka usahatani Kopi Libtukom di Tanjung Jabung Barat memerlukan tambahan biaya faktor domestik sebesar 0.195 atau lebih dari satu satuan. Korelasinya dengan faktor produksi adalah penggunaan faktorfaktor produksi pada usahatani Kopi Libtukom di Tanjung Jabung Barat dikategorikan cukup efisien.

\section{Analisis Keunggulan Komparatif}

Analisis keunggulan komparatif usahatani Kopi Libtukom di Kabupaten Tanjung Jabung Barat diukur dengan indikator Rasio Biaya Sumberdaya Domestik (DRCR) dan Keuntungan 
Sosial (SP). Rasio Biaya Sumberdaya Domestik (DRCR) di Kabupaten Tanjung Jabung Barat diperoleh dari keuntungan sosial Rp. 49.112.049,9/ha dengan nilai PCR yang didapatkan sebesar 0,176. Nilai DRCR merupakan rasio antara biaya faktor domestik dengan selisih antara penerimaan dengan biaya input tradable pada harga bayangan (sosial) atau harga yang didalamnya tidak terdapat kebijakan pemerintah.

Nilai DRCR yang diperoleh dari lokasi penelitian lebih kecil dari satu. Nilai tersebut mengindikasikan bahwa alokasi sumberdaya dalam sistem usahatani Kopi Libtukom di lokasi tersebut sudah mencapai efisiensi secara ekonomi sehingga memiliki keunggulan komparatif.

Jika nilai DRCR pada usahatani Kopi Libtukom di Tanjung Jabung Barat $(0,176)$ dibandingkan dengan nilai DRCR pada komoditas perkebunan lain yang memiliki input yang sama di Indonesia seperti Kakao di PTPN VIII Kebun Cikumpai Afedeling Rajamandala Bandung $(0,95)$ dalam penelitian Aliyatillah (2009), menunjukkan bahwa usahatani Kopi Libtukom di Tanjung Jabung Barat memiliki keunggulan komparatif lebih tinggi dibandingkan PTPN VIII Kebun Cikumpai Afedeling Rajamandala Bandung. Jika nilai tersebut dibandingkan dengan komoditas Karet di perkebunan rakyat Jambi dengan sistem monokultur dan agroforestry $(0,37$ dan 0,38$)$ dalam penelitian Rodgers (2008), menunjukkan bahwa komoditas ini lebih unggul secara komparatif dibandingkan komoditas Karet. Nilai DRCR yang diperoleh dari sistem usahatani Kopi Libtukom di Kabupaten Tanjung Jabung Barat $(0,176)$. Nilai tersebut mengindikasikan bahwa besarnya faktor domestik pada harga sosial yang diperlukan untuk meningkatkan nilai tambah kopi libtukom sebesar satu satuan. Kondisi ini mengindikasikan bahwa alokasi sumber daya dalam sistem usahatani kopi libtukom relatif lebih efisien.

Kondisi yang sama juga ditunjukkan oleh nilai keuntungan sosial (SP) sistem usahatani Kopi Libtukom di Tanjung Jabung Barat. Keuntungan sosial merupakan selisih antara penerimaan dengan seluruh biaya yang dikeluarkan pada sistem usahatani Kopi Libtukom per hektar pada harga bayangan (sosial), yakni harga yang tidak dipengaruhi oleh kebijakan pemerintah seperti subsidi dan pajak. 
Tabel 4 menunjukkan bahwa nilai SP yang diperoleh dari sistem komoditas Kopi Libtukom di Kabupaten Tanjung Jabung Barat Rp 49.112.049,9/ha. Hal ini mengindikasikan bahwa usahatani Kopi Libtukom di Tanjung Jabung Barat memiliki tingkat keunggulan komparatif. Rendahnya harga sosial dan penggunaan input tradable tersebut pada usahatani yang lebih intensif di Tanjung Jabung Barat menyebabkan biaya produksi pada harga sosial semakin kecil. Akibatnya, keuntungan sosial yang diperoleh dari sistem usahatani Kopi Libtukom di Tanjung Jabung Barat menjadi tinggi.

Nilai DRCR usahatani Kopi Libtukom di Tanjung Jabung Barat sebesar 0.176. Nilai DRCR $<1$ mengindikasikan adanya keunggulan komparatif suatu komoditi. Sehingga dapat dikatakan bahwa usahatani Kopi Libtukom di Tanjung Jabung Barat memiliki keunggulan komparatif atau dengan kata lain Kopi Libtukom di Tanjung Jabung Barat hanya membutuhkan biaya sumberdaya domestik sebesar 0.176 persen terhadap biaya impor yang dibutuhkan. Dengan kata lain, setiap US \$ 1.00 yang dibutuhkan untuk mengimpor produk tersebut, hanya membutuhkan biaya domestik sebesar US \$ 0.176, artinya untuk memenuhi kebutuhan domestik, maka usahatani Kopi Libtukom sebaiknya diproduksi sendiri di Tanjung Jabung Barat dan tidak perlu didatangkan atau diimpor dari daerah atau negara lain.

\section{d. Dampak Kebijakan Pemerintah terhadap Daya Saing Kopi Libtukom di Kabupaten Tanjung Jabung Barat}

Ukuran dampak divergensi dan kebijaksanaan pemerintah dalam Policy Analysis Matrix adalah Output Transfer (OT), Input Transfer (IT), Factor Transfer (FT) dan Net Transfer $(N T)$. Ukuran relatif ditunjukan oleh analisis koefisien proteksi output nominal atau Nominal Protection Coefficient on Output (NPCO), koefisien proteksi input nominal atau Nominal Protection Coefficient on Input (NPCI), koefisien proteksi efektif atau Effectif Protection Coeficient $(E P C)$.

Koefisien profitabilitas atau Profitability Coeficient (PC) dan rasio subsidi bagi produsen atau Subsidy Ratio to Producer (SRP) (Saptana dkk, 2008). Selengkapnya mengenai nilai masing-masing koefisien PAM tersebut seperti tersaji pada Tabel 5. Kebijakan 
pemerintah pada sektor pertanian dapat menentukan keberhasilan pengembangan usaha dalam rangka meningkatkan devisa. Kebijakan dapat mempengaruhi produksi maupun produktivitas suatu kegiatan ekonomi. Berdasarkan hal tersebut, kebijakan pemerintah diduga mampu mempengaruhi kondisi daya saing suatu komoditas.

Tabel 5. Hasil Koefisien PAM untuk Analisis Dampak Kebijakan Pemerintah terhadap Usahatani Kopi Libtukom Kabupaten Tanjung Jabung Barat

\begin{tabular}{|r|l|r|}
\hline No & \multicolumn{1}{|c|}{ Parameter } & \multicolumn{1}{|c|}{ Nilai } \\
\hline 1 & Privat Profitability (PP) & $43,690,812.240$ \\
\hline 2 & Social Profitability (SP) & $49,112,049.898$ \\
\hline 3 & Output Transfer (OT) & $(-)$ 5,323,323.766 \\
\hline 4 & Input Transfer (IT) & $3,707.956$ \\
\hline 5 & Factor Transfer (FT) & $94,205.936$ \\
\hline 6 & Net Transfer (NT) & $(-)$ 5, \\
\hline 7 & Private Cost Ratio (PCR) & 0.195 \\
\hline 8 & Domestic Resource Cost Ratio (DRCR) & 0.170 \\
\hline 9 & Nominal Protection Coefficient (NPC) : & 0.912 \\
\hline & a. On Tradeble Outputs (NPCO) & 1.006 \\
\hline & b. On Tradeble inputs (NPCI) & 0.911 \\
\hline 10 & Effective Protection Coefficient (EPC) & 0.890 \\
\hline 11 & Profitability Coeficient (PC) & $(-) 0.09$ \\
\hline 12 & Subsidy Ratio to Producers (SRP) & \\
\hline & & \\
\hline
\end{tabular}

\section{Sumber : Olahan Data Primer}

\section{Dampak Kebijakan Output}

Nilai output transfer

menunjukkan kebijakan output yang sebaiknya dilaksanakan oleh pemerintah terhadap usahatani Kopi Libtukom di Kabupaten Tanjung Jabung Barat . Nilai OT yang diperoleh pada Tabel 5 memperlihatkan nilai yang negatif. Artinya bahwa harga output di pasar domestik lebih rendah dibandingkan harga internasionalnya.
Lebih lanjut, hal ini mengindikasikan adanya kebijakan pajak atau pungutan terhadap output yang dibebankan kepada petani produsen secara tidak langsung. Secara teori ekonomi hal ini menunjukkan adanya surplus konsumen namun di sisi lain terjadi minus pada produsen, yaitu petani. Secara sederhana dapat dikemukakan bahwa petani sebagai produsen menerima harga output (hasil 
panen Kopi Libtukom) lebih rendah dari harga yang seharusnya.

Sesuai dengan informasi dari hasil wawancara, ditemukan bahwa umumnya pengambilan pedagang untuk hasil Kopi Libtukom petani antara Rp. 27.000,- s.d. Rp. 35.000/kg. Harga ini masih jauh atau tidak bisa menutupi biaya produksi yang dikeluarkan petani setiap musimnya. Untuk lebih mempertegas hasil OT tersebut maka perlu diperkuat dengan nilai Nominal Protection Coefficient on Output (NPCO).

NPCO menunjukkan dampak kebijakan (kegagalan pasar yang tidak dikoreksi oleh kebijakan efisiensi) yang menyebabkan divergensi antara harga privat dan sosial terhadap harga output. Tabel 5 menunjukkan nilai NPCO $<1$, yang berarti bahwa kebijakan pemerintah selama ini bersifat disinsentif atau tidak protektif terhadap output.

Seharusnya pemerintah menetapkan kebijakan harga pembelian Kopi Libtukom daerah, sehingga tidak terjadi ketimpangan dalam pelaksanaannya di lapangan. Hal ini menyebabkan market failure (kegagalan pasar), sebagai akibat dari permainan harga oleh para pedagang pengumpul, sementara petani tidak punya pilihan lain karena terdesak kebutuhan, dampaknya pada rendahnya tingkat pendapatan petani, atau rendahnya profitabilitas privat seperti terlihat pada Tabel 5 diatas.

Selain itu tidak ada kebijakan output yang diberlakukan terhadap komoditas Kopi Libtukom untuk menetapkan standar harga juga salah satu hal yang mendorong ketidakstabilan harga Kopi Libtukom di tingkat petani sehingga terjadi kebijakan automatic detention yang ditetapkan oleh negara pengimpor kopi libtukom seperti Singapura dan Malaysia.

Kebijakan ini berupa pemotongan harga Kopi Libtukom karena kualitas Kopi Libtukom yang dihasilkan oleh produsen Kopi Libtukom di Indonesia rendah. Pemotongan harga ini berimplikasi pada penurunan harga di tingkat petani. Untuk usahatani Kopi Libtukom di Kabupaten Tanjung Jabung Barat belum mampu mendorong terbentuknya harga Kopi Libtukom yang relatif lebih tinggi. Kondisi ini berpengaruh terhadap semakin besarnya penerimaan dan keuntungan privat dari sistem usahatani tersebut. Peningkatan keuntungan privat menunjukkan peningkatan 
keunggulan kompetitif usahatani tersebut di Kabupaten Tanjung Jabung Barat.

\section{Dampak Kebijakan Input}

Hasil Input Transfer (IT) Nominal Protection Coefficient on Input (NPCI) dan factor Transfer (FT) pada Tabel 5 tersebut menggambarkan dampak kebijakan input secara keseluruhan terhadap usahatani Kopi Libtukom di Kabupaten Tanjung Jabung Barat. Nilai-nilai IT, NPCI dan FT tersebut menunjukkan adanya kebijakan yang bersifat protektif terhadap produsen input tradable dan faktor domestik (non tradable). Produsen input dan faktor domestik dalam hal ini termasuk juga kios-kios saprodi dan para penyelia tenaga kerja sewaan atau kelompok-kelompok tanam.

Nilai TI merupakan selisih antara biaya input tradable pada harga privat dengan biaya input tradable pada harga sosial (bayangan). Beberapa bentuk kebijakan tersebut antara lain berupa bantuan pemerintah seperti bibit tanaman Kopi Libtukom dan pupuk anorganik, serta kebijakan subsidi dan penetepan Harga Eceran Tertinggi (HET) untuk pupuk anorganik seperti pupuk Urea dan SP-36.
Besarnya dampak kebijakan pemerintah terhadap input produksi Kopi Libtukom ditunjukkan oleh nilai Transfer Input (TI), Koefisien Proteksi Input Nominal (NPCI), dan Transfer Faktor (TF). Data mengenai besarnya TI, NPCI dan TF dalam sistem komoditas Kopi Libtukom di Kabupaten Tanjung Jabung Barat dapat dilihat pada Tabel 5 untuk transfer input masih sangat kecil yaitu 3,707.956 dengan nilai NPCL yang diperoleh 1.006 yang artinya bersifat protektif terhadap input (subsidi terhadap input tradable).

Kondisi ini terjadi karena penggunaan input tradable (pupuk anorganik dan pestisida) pada usahatani Kopi Libtukom yang kurang di Kabupaten Tanjung Jabung Barat. Kondisi ini berpengaruh terhadap semakin kecilnya biaya produksi pada harga sosial dan semakin besar keuntungan sosial yang diperoleh dari sistem usahatani tersebut. Kenaikan keuntungan sosial menunjukkan keunggulan komparatif usahatani Kopi Libtukom tersebut di Kabupaten Tanjung Jabung Barat. Kondisi tersebut mengindikasikan bahwa di bawah kebijakan input tradable, usahatani Kopi Libtukom menyebabkan 
keunggulan komparatif komoditas Kopi Libtukom di Kabupaten Tanjung Jabung Barat mengalami kenaikan.

Selain input tradable, input lain yang digunakan dalam proses produksi adalah input domestik (faktor domestik). Harga atas input tersebut ditentukan oleh mekanisme pasar di dalam negeri. Transfer Faktor (TF) merupakan indikator dampak kebijakan pemerintah terhadap input produksi tersebut. TF merupakan selisih antara biaya input domestik yang dihitung pada harga privat denga biaya input produksi pada harga bayangan (ekonomi). Kebijakan pemerintah untuk input domestik dilakukan dalam bentuk kebijakan subsidi (positif atau negatif). Nilai tersebut menunjukkan bahwa terdapat implisit pajak atau transfer (intensif) dari petani Kopi Libtukom di Kabupaten Tanjung Jabung Barat kepada produsen input domestik sehingga petani Kopi Libtukom harus membayar input domestik tersebut lebih mahal dari harga sosialnya. Beberapa bentuk kebijakan yang menyebabkan timbulnya implisit pajak tersebut antara lain Pajak Bumi dan Bangunan (PBB) dan Pajak
Pertambahan Nilai (PPN) atas pestisida.

Di sisi lain, harga privat input domestik di Kabupaten Tanjung Jabung Barat relatif lebih kecil yaitu 8.184.083 per hektar kondisi ini terjadi karena usahatani Kopi Libtukom yang lebih intensif dan lebih banyak menggunakan sumberdaya modal dan tenaga kerja. Akibatnya, biaya atas penggunaan input tersebut semakin besar.

\section{Dampak Kebijakan Input-Output}

Secara keseluruhan hasil perhitungan Effective Protection Coefficient (EPC), Net Transfer (NT), Profitability Coeficient (PC) dan Subsidy Ratio to Producers (SRP) pada Tabel 15 menunjukkan belum adanya keberpihakan pemerintah terhadap usahatani Kopi Libtukom karena tingkat proteksi yang rendah terhadap hasil Kopi Libtukom petani, dimana hal ini berdampak pada pengurangan surplus petani yang sangat merugikan petani kecil. Sebagai contoh nilai SRP $<0$ (negatif) menunjukkan bahwa kebijakan pemerintah yang berlaku selama ini menyebabkan produsen mengeluarkan biaya produksi lebih besar dari opportunity cost. 
Secara rinci dapat dikemukakan bahwa nilai PC usahatani Kopi Libtukom sebesar 0.890 menunjukkan bahwa rasio keuntungan usahatani Kopi Libtukom kurang dari 0.1 persen atau dengan NT yang negatif (Rp. (-) 5.421.237,658 hanya mendatangkan rasio keuntungan kurang dari 0.09 persen terhadap harga privat. Pengertian lain bahwa terdapat kebijakan pemerintah atau distorsi pasar pada input dan output secara keseluruhan yang merugikan petani.

Nilai SRP -0.09 menunjukkan bahwa petani produsen mengeluarkan biaya produksi yang besar. Hal ini mungkin saja tidak akan terjadi seandainya pemerintah dapat menerapkan kebijakan tarif impor terhadap produk kopi impor, sehingga dapat meningkatkan harga jual produk domestik, dampaknya pada peningkatan tingkat penerimaan petani dan profitabilitas privat.

$$
\text { Rosihan (2008), dalam }
$$
penelitiannya mengemukakan bahwa komoditas pertanian, menggunakan teknologi rekomendasi maupun teknologi petani, asalkan komoditas tersebut digunakan untuk promosi ekspor maka memperoleh proteksi dari pemerintah yang ditandai dengan nilai
EPC > 1. Sedangkan komoditas yang digunakan untuk orientasi subtitusi impor dan perdagangan antar daerah tidak memperoleh proteksi pada harga outputnya, namun hanya memperoleh subsidi pada input usahataninya. Sehingga, jika dihubungkan dengan hasil penelitian ini maka dapat dikemukakan bahwa usahatani Kopi Libtukom di Kabupaten Tanjung Jabung Barat pun harus dipacu lagi, berdaya saing tinggi dengan meningkatkan produksi, memperbaiki kualitas produk melalui pengembangan teknologi pasca panen melalui bantuan alat pasca panen serta peningkatan nilai tambah produk (pengembangan produk turunan) agar supaya kebijakan pemerintah dapat lebih berpihak pada usahatani Kopi Libtukom tersebut.

\section{e. Sensitivitas}

\section{Penurunan Output Sebesar 5 Persen.}

Berdasarkan data yang didapat jika penurunan dikarenakan beberapa faktor antara lain adanya anomali cuaca yang ekstrim dan alih fungsi lahan. Selain itu pola pemupukan yang tidak teratur, menyebabkan proses pertumbuhan menjadi terhambat, hal ini terjadi karena alokasi untuk pemupukan tidak tersedia pada saat waktu pemupukan tiba. Jika penurunan output sebesar 5 persen tidak terjadi perubahan 
yang signifikan, dari hasil perhitungan berdasarkan keuangan dan analisis ekonomi hasil, pendapatan keuangan bersih yang diperoleh Kopi Libtukom secara privat di Kabupaten Tanjung Jabung Barat menunjukkan bahwa ratarata total penerimaan mencapai $\mathrm{Rp}$. 52.207.921,20/ha, sedangkan total biaya yang dikeluarkan petani sebesar Rp. 11.264.894,3/ha. Sehingga keuntungan bersih (net profit) sebesar Rp. 40.943.026,9/ha. Ini berarti bahwa usahatani Kopi Libtukom masih menguntungkan bagi petani secara individual pada saat output kurang 5 persen. Dengan kata lain, biaya produksi yang dikeluarkan oleh masingmasing petani untuk satu tahun dapat ditutupi oleh harga kopi libtukom. Ini berarti bahwa usahatani Kopi Libtukom menguntungkan bagi petani secara individual. Dengan kata lain, biaya produksi yang dikeluarkan oleh masingmasing petani untuk budidaya Kopi Libtukom dapat ditutupi oleh harga jual yang diperoleh.

\section{Penurunan Harga Output Sebesar 10 Persen.}

Besarnya dampak jika penurunan harga Kopi Libtukom domestik sebesar 10 persen, pada daya saing usahatani Kopi Libtukom di Kabupaten Tanjung Jabung Barat dapat dilihat dari besarnya perubahan indikator Keuntungan Privat (PP) dan Keuntungan Sosial (SP) yang menunjukkan bahwa penurunan harga Kopi Libtukom domestik sebesar 10 persen, menyebabkan perubahan pada SP yang diperoleh dari sistem usahatani Kopi Libtukom di Kabupaten Tanjung Jabung Barat dan juga menyebabkan penurunan pada PP.

Perbandingan itu dapat dilihat untuk PP diperoleh berdasarkan keuangan dan analisis ekonomi hasil, pendapatan keuangan bersih yang diperoleh Kopi Libtukom secara privat di Kabupaten Tanjung Jabung Barat menunjukkan bahwa rata-rata total penerimaan yang menurun dari penerimaan awal. Setelah dilakukan penghitungan dengan menurunkan harga Kopi Libtukom sebesar 10 persen diperolah untuk keuntungan privat Rp. 49.460.135.87/ha sedangkan total biaya yang dikeluarkan petani tetap sebesar Rp. 11.264.894,2/ha. Sehingga keuntungan bersih (net profit) sebesar Rp 38.195.241.6/ha. Ini berarti bahwa usahatani Kopi Libtukom masih menguntungkan bagi petani secara individual.

Dengan kata lain, biaya produksi yang dikeluarkan oleh masing-masing petani untuk satu musim dapat ditutupi 
oleh harga jual Kopi Libtukom. Hal ini terjadi karena usahatani yang dilakukan di Kabupatan Tanjung Jabung Barat mampu meningkatkan jumlah produksi Kopi Libtukom sehingga ketika harga privat Kopi Libtukom mengalami penurunan maka besarnya penerimaan dan keuntungan privat yang diperoleh juga mengalami penurunan yang lebih tinggi.

Penurunan keuntungan privat mengindikasikan penurunan pada keunggulan kompetitif usahatani komoditas tersebut. Kondisi ini mengindikasikan bahwa penurunan harga Kopi Libtukom domestik sebesar 10 persen, menyebabkan usahatani Kopi Libtukom di Kabupaten Tanjung Jabung Barat berpengaruh terhadap semakin besarnya penurunan keunggulan kompetitif usahatani Kopi Libtukom di kabupaten Tanjung Jabung Barat.

\section{Peningkatan Harga Pupuk Anorganik}

Besarnya dampak perubahan kebijakan pemerintah berupa kenaikan harga pupuk urea sebesar 12,5 pada daya saing usahatani Kopi Libtukom di Kabupaten Tanjung Jabung Barat tidak terlalu berpengaruh terhadap
Keuntungan Privat (PP) dan Keuntungan Sosial (SP) hal ini dikarenakan Kopi Libtukom di Kabupaten Tanjung Jabung Barat tidak terlalu menggunakan pupuk anorganik. Setelah dilakukan penghitungan dengan menaikkan harga pupuk pupuk urea sebesar 12,5 persen masih untuk keuntungan privat Rp. 54.955.706,52/ha sedangkan total biaya yang dikeluarkan petani sebesar Rp. 11.284.539,02/ha. Sehingga keuntungan bersih (net profit) sebesar Rp 43.671.167,5/ha.

\section{KESIMPULAN DAN SARAN}

\section{Kesimpulan}

1. Usahatani Kopi Libtukom di Kabupaten Tanjung Jabung Barat memiliki keunggulan komparatif dan kompetitif yang ditandai dengan nilai PCR dan DRCR yang di peroleh <1, Untuk PCR diperoleh 0,195 dan DRCR 0,176.

2. Kebijakan-kebijakan pemerintah untuk usahatani Kopi Libtukom belum menunjukkan keberpihakan yang menguntungkan petani kecil dan kelangsungan hidup usahataninya

3. Hasil simulasi sensitivitas usahatani Kopi Libtukom di Kabupaten Tanjung Jabung Barat masih tetap memiliki keunggulan 
komparatif dan kompetitif dengan nilai PCR dan DRCR, baik terhadap output sebesar 5 persen, penurunan harga output sebesar 10 persen serta peningkatan harga pupuk anorganik sebesar 12,5 persen.

\section{Saran}

1. Bagi pemerintah, peningkatan keunggulan komparatif dan kompetitif usahatani Kopi Libtukom dapat ditempuh melalui upaya usahatani dengan penggunaan input tradable yang mengandung komponen impor yang semakin menurun.

2. Keberhasilan pengembangan Kopi Libtukom tidak hanya ditentukan oleh tingginya produktivitas saja namun juga melibatkan kualitas dari produk itu sendiri. Agar komoditas tersebut mampu bersaing dan memiliki keunggulan kompetitif, maka harus dapat menghasilkan Kopi Libtukom dengan kualitas yang baik, sehingga tekhnik pasca panennya pun harus lebih diperhatikan dan ditangani lebih baik. Untuk itu perlu adanya pelatihan dan pendampingan teknologi yang dilakukan secara rutin kepada para petani agar hal ini dapat terwujud. Bagi petani, aktivitas kelompok tani sebaiknya lebih ditingkatkan.

3. Bagi pihak akademisi yang tertarik untuk melakukan penelitian lanjutan, dapat membahas strategi pengembangan daya saing Kopi Libtukom dan industri pengolahan Kopi Libtukom Indonesia dalam menghadapi era perdagangan bebas dunia.

\section{DAFTAR PUSTAKA}

Aliyatillah, FM. 2009. Analisis Daya Saing dan Dampak Kebijakan Pemerintah Terhadap Komoditas Kakao (Kasus:PTPN VIII Kebun Cikumpay Delling Rajamandala Bandung) [Skripsi]. Bogor : Fakultas Ekonomi dan Manajemen, Institut Pertanian Bogor.

Fitria Astriani. 2011. Analisis Keunggulan Komparatif dan Kompetitif Usahatani Jagung Jambu Biji Kecamatan Tanah Sareal. Institut Pertanian Bogor. Bogor.

Gittinger. 1986. Analisa Ekonomi Proyek-Proyek Pertanian. Jakarta : UI Press

Monke, EA and S. Pearson. 1989. The Policy Analysis Matrix For Agricultual Development. Cornell University Press, London.

Novianti, T. 2003. Analisis Dampak Kebijakan Pemerintah Terhadap Daya Saing Komoditas Unggulan [Tesis]. Bogor : Sekolah Pascasarjana. Institut Pertanian Bogor. 
Pearson S, Gotsch C, Bahri S. 2004. Aplikasi Policy Analysis Matrix pada Pertanian Indonesia. Jakarta : Yayasan Obor Indonesia.

Rodgers, A. 2008. Economic Analysis Of Smallholder Rubber Agroforestry System Efficiency In Jambi Indonesia [Tesis]. Bogor: Sekolah Pascasarjana, Institut Pertanian Bogor.

Rosihan, A. 2008. Analisis Tingkat Daya Saing Ekspor Komoditi Perkebunan Indonesia. Universitas Brawijaya Malang.
AGRISE Volume VIII No. 2 Bulan Mei 2008 ISSN: 14121425

Saptana, dkk. 2001. Analisis Keunggulan Komparatif Komoditas Unggulan Hortikultura. Bogor : Laporan Hasil Penelitian. Puslitbang Sosek Pertanian. Badan Litbang Pertanian, Departemen Pertanian RI. Available From URL : http:www.ipard.com/artperkebun di akses 18 Mei 2016 